\title{
Henoch-Schönlein Purpura in Adults: a Case Series from a Multidisciplinary Study Group
}

\section{Púrpura de Henoch-Schönlein em Adultos: uma Série de Casos de um Grupo de Estudo Multidisciplinar}

\author{
Boris A. Cruz ${ }^{(1)}$, Ana Lúcia V. Vaz de Melo $^{(2)}$, Mariana P. G. Ubirajara Silva ${ }^{(3)}$, Alberto Kazuo Fuzikawa ${ }^{(4)}$, \\ Zaida J. Cabrera ${ }^{(5)}$, Hélcio Antônio Tavares Filho ${ }^{(6)}$, Felipe Fagioli ${ }^{(7)}$, Carolina Rutkowski ${ }^{(7)}$, \\ Abrahão Salomão Filho ${ }^{(8)}$, Austenir Maciel Coelho ${ }^{(9)}$, Rejane Pinheiro Damasceno ${ }^{(10)}$
}

\begin{abstract}
Background: Henoch-Schönlein purpura (HSP) is a systemic vasculitis involving small vessels with the deposition of immune complexes containing IgA. It has been extensively studied in children, but in adults, its natural history is much less known. Objectives: to report a series of patients with HSP presenting in their adulthood. Patients and Methods: the Minas Gerais Vasculitis Study Group's Members (MGVSG) were invited to report patients with HSP who appeared in their adulthood. A standardized retrospective chart review was done. Results: eleven patients, two male and nine female, age $39.4+/-20.1$ yearsold were studied. Nine patients presented purpura, seven presented arthritis, four patients had gastrointestinal involvement and ten patients (91\%) presented glomerulonephritis $(G N)$. Eight patients were subjected to renal biopsies. Six of them presented endocapillary proliferative GN and only two of them had minimal mesangial proliferation. In the other three patients, HSP was confirmed by skin biopsies. All patients received steroids, in five of them steroids were combined with other immunosuppressive agents. After a follow-up of 39.0 $+/-64.6$ months, four patients (36\%) presented impairment of renal function, but only one (9\%) developed end stage renal disease and was successfully appeared to renal transplantation. At the end of follow-up, seven patients (64\%) are in complete remission and four in partial remission. Conclusion: in adulthood, HSP represents a distinct clinical syndrome with a higher frequency of renal involvement and more severe systemic vasculitis. Nevertheless, the final outcome in this series was as good as reported in children, maybe due to aggressive immunosuppressive therapy.
\end{abstract}

Keywords: Henoch-Schönlein purpura, systemic vasculitis, adults.

\section{RESUMO}

Introdução: púrpura de Henoch-Schönlein (PHS) é uma vasculite sistêmica que acomete vasos de pequeno calibre com depósitos de imunocomplexos contendo IgA. Esta vasculite já foi extensamente estudada em crianças, mas sua história natural em adultos é menos conhecida. Objetivos: descrever uma série de pacientes adultos com PHS. Pacientes e Métodos: membros do Grupo Mineiro de Estudo das Vasculites foram convidados a reportar pacientes com PHS apresentando-se na idade adulta. Foi realizada revisão padronizada de prontuários. Resultados: 11 pacientes, dois homens e nove mulheres, com idade \pm desvio padrão (DP) de $39,4+/-20,1$ anos foram estudados. Nove pacientes apresentaram púrpura; sete apresentaram artrite; quatro apresentaram envolvimento gastrintestinal e dez (91\%) pacientes apresentaram glomerulonefrite (GN). Oito pacientes foram submetidos à biópsia renal. Seis deles apresentaram GN endocapilar proliferativa e dois apresentaram apenas proeminência mesangial mínima. Em outros três pacientes, o diagnóstico de PHS foi confirmado através de biópsia de pele. Todos os pacientes receberam corticóide, em cinco associado a outros agentes imunossupressores. Após seguimento (média \pm DP) 39,0 \pm 64,6 meses, quatro pacientes (36\%) apresentaram comprometimento da função renal, mas apenas um $(9 \%)$ desenvolveu insuficiência renal terminal e foi submetido a transplante renal com sucesso. Após o seguimento, sete (64\%) estão em remissão completa e quatro em remissão parcial. Conclusão: em adultos, PHS representa uma entidade clínica distinta, com maior freqüência de envolvimento renal e vasculite sistêmica mais grave. Entretanto, o prognóstico nesta série foi tão bom quanto em crianças, talvez pela terapia imunossupressiva mais vigorosa.

Palavras-chave: púrpura de Henoch-Schönlein, vasculite sistêmica, adultos.

Minas Gerais Vasculitis Study Group. Received in 02/09/06. Approved, after review, in 08/10/06.

1. Assistant-Physician, Rheumatology Department, Biocor Instituto.

2. Head of Rheumatology Department, Biocor Instituto.

3. Resident of Internal Medicine Department, Biocor Instituto

4. Head of Internal Medicine Department, Biocor Instituto.

5. Resident of Nephrology Department, Biocor Instituto.

6. Head of Nephrology Department, Biocor Instituto.

7. Assistant-Physician of Nephrology Department, Instituto Mineiro de Nefrologia.

8. Coordinator of Instituto Mineiro de Nefrologia.

9. Resident of Rheumatology Department, Hospital Governador Israel Pinheiro.

10. Medical Assistant of Rheumatology Department, Hospital Governador Israel Pinheiro.

Corresponding author: Boris A. Cruz, Rua Fernandes Tourinho, 999/107, CEP 30112-000, Belo Horizonte, MG, Brasil, Phone: 55-31-3284-7766, Fax: 55-31-3225-5712, e-mail: boriscruz@terra.com.br 


\section{INTRODUCTION}

Henoch-Schönlein purpura (HSP) is a systemic small vessel vasculitis, characterized by the deposition of $\operatorname{Ig} A$ containing immune complexes in the skin, gastrointestinal tract, joints, and kidneys. The dominant clinical features of HSP are cutaneous purpura, arthritis, abdominal pain, gastrointestinal bleeding, and nephritis. The overall prognosis is good with a reported mortality of less than $1 \%$ and low morbidity ${ }^{(1,2)}$.

HSP primarily affects children, and its incidence is approximately 15 cases /100,000 children per year. However, HSP is much rare in adults and the severity of its clinical manifestations seem to be different to the presentation in children ${ }^{(3-6)}$. We retrospectively analyzed 11 adults who suffered from HSP. The goal of this study was to describe the clinical, laboratory, and histological characteristics, treatment and follow-up of these patients.

\section{PATIENTS AND METHODS}

Members of the Minas Gerais Vasculitis Study Group (MGVSG) were invited to report patients with HSP presented in adulthood, according to predefined inclusion criteria (see ahead). The MGVSG is a multi-disciplinary and multi-institutional project developed in Minas Gerais to study clinical, epidemiologic and therapeutic aspects of vasculitis and to promote diffusion of knowledge in our medical community. It includes now more than a hundred surgeons and physicians from different institutions and most medical specialties. Patients should be followed by the reporting physician and their medical charts should be available for standardized review to maximize information accuracy (demographics, clinical and laboratory data, treatment and follow-up were recorded).

Inclusion criteria were: i) age $\geq 18$ years-old at diagnosis; ii) histological confirmation of vasculitis and/or glomerulonephritis ( $G N$ ) with predominant IgA immune deposits and iii) at least two of the following: a) cutaneous vasculitis; b) arthritis; c) hematuria and/or proteinuria; d) abdominal pain, diarrhea or melena. Renal insufficiency was defined as creatinine clearance $(\mathrm{CrCl})<50 \mathrm{ml} / \mathrm{min}$. Proteinuria was defined as proteinuria $>0.150 \mathrm{~g} /$ day, and nephrotic range proteinuria as proteinuria $>3.5 \mathrm{~g} /$ day. Hematuria was defined as $>10$ red cells $/ \mathrm{mm} 3$ in the urine. Partial remission was defined by the presence of mild symptoms responsible to steroids and requiring no additive immunosuppressive therapy. Complete clinical remission was defined by no clinical symptoms under none or low dose steroids (prednisone dose $\leq 10 \mathrm{mg}$ /day or equivalent) and/ or stable dose maintenance immunosuppressive therapy. Inclusion criteria and all definitions were established before inclusion of patients, according to a consensus of the MGVSG coordination committee.

\section{RESULTS}

Eleven patients, two male and nine female, age (mean \pm standard deviation [SD]) $39.5 \pm 20.1$ years-old (median 30 years-old) were studied. Clinically, nine patients (81\%) presented purpura, in two of them with necrotic skin ulcers. (Figure 1) Sixty-four percent of the patients presented arthritis, mainly in knees and ankles. Ten patients (91\%) presented $G N$, in three of them as a rapid progressive $G N$ with renal insufficiency and in two of them with nephrotic range proteinuria. Four patients (36\%) had gastrointestinal (GI) involvement clinically expressed as abdominal pain and bloody diarrhea. Only one patient reported prodromic infection. Vasculitis related symptoms were present for (mean $\pm S D) 13.1 \pm 17.2$ months (median 6 months) before diagnosis.

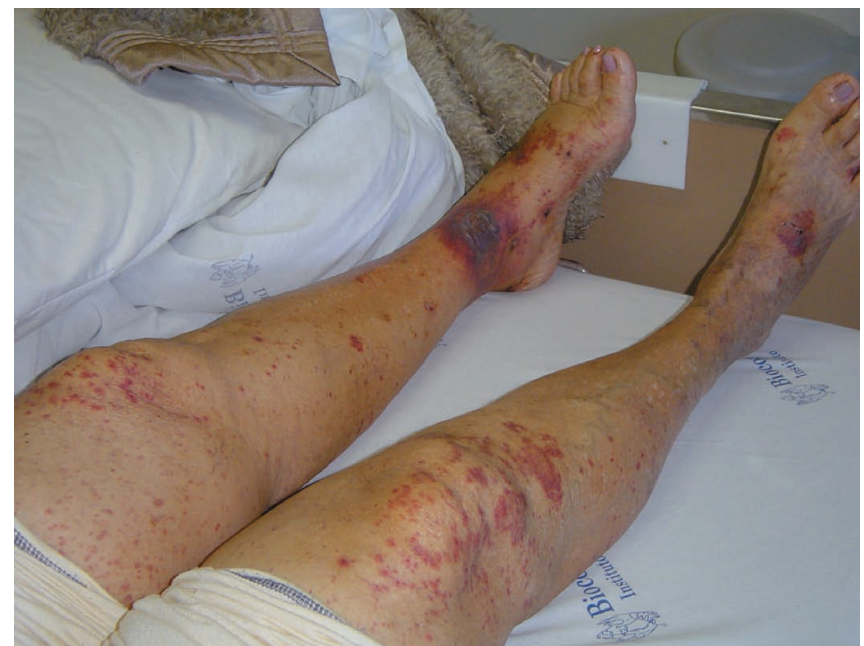

Figure 1 - Purpura and necrotic skin ulcer in a patient with Henoch-Schönlein Purpura (Patient 5).

Five out of eight patients (62.5\%) presented high IgA blood levels. Three patients presented rheumatoid factor positivity and one patient had a positive anti-nuclear antibody test (ANA: 1/160 speckled pattern). In this patient, no other specific autoantibodies were present, she did not fulfill classification criteria for systemic lupus erythematosus and renal biopsy was suggestive of HSP due to predominant IgA deposition (Patient 1). Only one 
patient had evidence of serum complement consumption.

Eight patients were subjected to renal biops. Six of them presented endocapillary proliferative $G N$ and two had only minimal mesangial proliferation. In the other three patients, $H S P$ was confirmed by the evidence of vasculitis in skin biopsies. In all biopsies, immunofluorescence confirmed predominant IgA deposition (Figure 2).

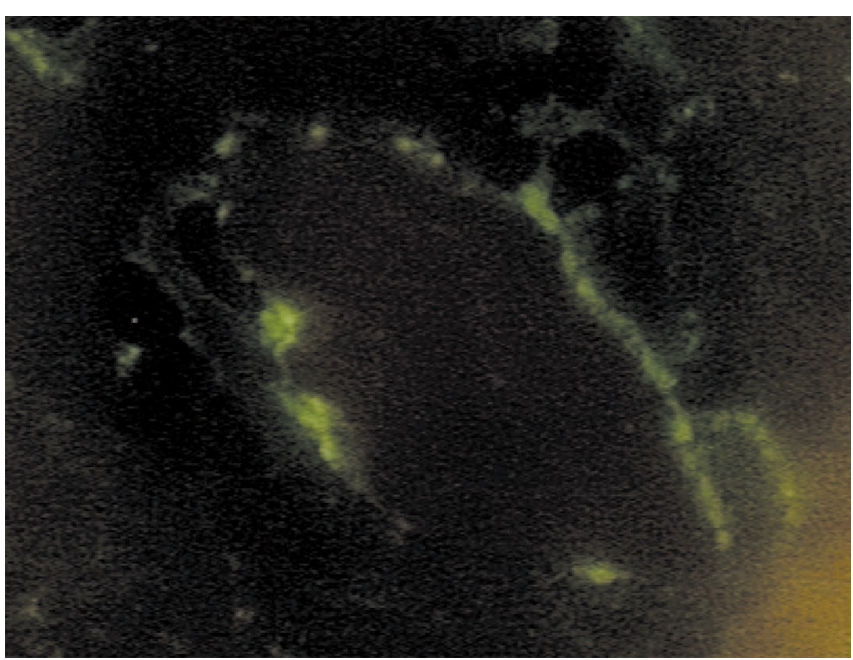

Figure 2 - Immunofluorescence of a skin biopsy with vasculitis showing deposition of IgA (Patient 4).

All patients received steroids, mainly prednisone $1 \mathrm{mg} / \mathrm{Kg} /$ day initially and then progressively tapered according to clinical judgment. Five patients received other immunosuppressive agents. After a follow-up of (mean \pm SD) $39.0 \pm 64.6$ months (median 12 months), four patients (36\%) presented renal insufficiency. One patient developed end stage renal disease and he was successfully subjected to renal transplantation. At the end of follow-up, seven patients (64\%) are in complete remission and four patients are in partial remission. Table 1 summarizes demographics, clinical, laboratory and histological features, treatment and follow-up of the patients (Table 1).

\section{DISCUSSION}

Henoch-Schönlein purpura (HSP) is the most common systemic vasculitis of childhood, usually with a benign course and in most patients requiring just supportive treatment ${ }^{(1,2)}$. However, several series suggest that spontaneous disease resolution in adults is less common than in children and the risk of progression to renal insufficiency seems to be much higher. Series of unselected children indicate that up to $90 \%$ of patients achieve resolution of the disease with a few mild or no sequelae and only 2-13\% eventually develop renal failure $^{(7,8)}$. Conversely, end stage renal disease is reported in up to $60 \%$ of adult HSP patients ${ }^{(3,5)}$. Nevertheless, most series studied selected patients whose disease exhibited renal involvement severe enough to warrant renal biopsy ${ }^{(4,}$ 6). Others studies have also suggested that cutaneous ulcers are more frequent in adult patients ${ }^{(6)}$. In our patients, we could verify a high frequency of severe renal involvement. Necrotic purpura with cutaneous ulcers were also more prevalent than usually reported in children. Although small, our series is representative, since it includes patients referred from different medical specialties. It reduces selection bias, but we can not exclude referral or memory bias because physicians were invited to report their patients and therefore this series is not exhaustive.

IgA seems to play a pathogenic role in HSP, as supported by its presence in cryoprecipitates and the finding of an increased number of circulating IgA-secreting cells in patients with active $H S P^{(9,10)}$. Most of our patients presented high IgA blood levels. When combined with selected clinical features, we understand that it should heighten scrutiny for the diagnosis of HSP. Nevertheless, the definite diagnosis should be based on the histological evidence of vasculitis or GN with IgA immune deposits as it was defined by the Consensus Conference on the Nomenclature of Systemic Vasculitides $^{(11)}$.

Although a skin biopsy is rarely needed in order to diagnose HSP in children, it may be necessary in adults ${ }^{(2)}$. $A$ wider spectrum of clinical associations are observed in adult patients with cutaneous vasculitis and a skin biopsy is a simple procedure that can confirm the diagnosis of HSP by the demonstration of $\mathrm{IgA}$ deposition on direct immunofluorescence in and around blood vessel walls ${ }^{(3,11}$, 12). We understand that renal biopsy should be reserved to patients who do not present cutaneous vasculitis or patients with more severe clinical features such as nephrotic range proteinuria or rapidly progressive GN, since histological parameters are independent prognostic factors for end stage renal disease and may help treatment decision ${ }^{(6,8)}$.

The efficacy of corticosteroids and/or immunosuppressive agents in the treatment of HSP is a subject of controversy. No study has so far been able to confirm the efficacy of treatment of HSP, but most reports suggest that adults may benefit more often from immunosuppressive therapy than children ${ }^{(3,4,6)}$. In our series, corticosteroids were prescribed due to refractory skin lesions, abdominal pain with gastrointestinal bleeding, or severe nephropathy. Immunosuppressive agents were used 
TABLE 1

DEMOGRAPHICS, CLINICAL AND LABORATORIAL FEATURES, HISTOLOGY, TREATMENT AND FOLLOW-UP OF PATIENTS WITH HENOCH-SCHÖNLEIN PURPURA PRESENTING IN ADULTHOOD $(N=10)$

\begin{tabular}{|c|c|c|c|c|c|}
\hline Patient & $\begin{array}{l}\text { Age/ } \\
\text { gender }\end{array}$ & $\begin{array}{c}\text { Main clinical and laboratorial } \\
\text { features }\end{array}$ & Histological diagnosis & Treatment & Evolution \\
\hline 1 & 42/female & $\begin{array}{l}\text { Nephrotic range proteinuria and knee/ } \\
\text { ankle arthritis. Positive ANA (1/160 } \\
\text { speckled pattern) }\end{array}$ & $\begin{array}{l}\text { Endocapillary proliferative GN } \\
\text { with IgA deposition }\end{array}$ & $\begin{array}{l}\text { Steroids, AZA, } \\
\text { MTX }\end{array}$ & Remission of GN, residual arthritis (PR) \\
\hline 2 & 64/female & $\begin{array}{c}\text { Purpura, ankle arthritis, nephrotic range } \\
\text { proteinuria followed by RPGN. } \uparrow \text { IgA, } \\
\text { Positive } R F \text { and } \downarrow \text { complement }\end{array}$ & $\begin{array}{l}\text { Endocapillary proliferative GN } \\
\text { with IgA deposition }\end{array}$ & Steroids, CYC & $\begin{array}{l}\text { Remission of all vasculitis related } \\
\text { symptoms (CR). Moderate renal } \\
\text { insufficiency }\end{array}$ \\
\hline 3 & 23/female & $\begin{array}{c}\text { Purpura, abdominal pain and melena, } \\
\text { hematuria, } \uparrow \text { IgA blood level }\end{array}$ & $\begin{array}{l}\text { Cutaneous leukocytoklastic } \\
\text { vasculitis with IgA deposition }\end{array}$ & Steroids & $\begin{array}{l}\text { Remission of all vasculitis related } \\
\text { symptoms }(C R)\end{array}$ \\
\hline 4 & 23/female & $\begin{array}{c}\text { Purpura and necrotic skin ulcers, ankle } \\
\text { arthritis, abdominal pain and melena. } \\
\qquad \uparrow \text { IgA blood level }\end{array}$ & $\begin{array}{l}\text { Cutaneous leukocytoklastic } \\
\text { vasculitis with IgA deposition }\end{array}$ & $\begin{array}{c}\text { Steroids, } M T X, \\
A Z A,\end{array}$ & $\begin{array}{c}\text { Residual cutaneous vasculitis and } \\
\text { arthritis (PR) }\end{array}$ \\
\hline 5 & 74/female & $\begin{array}{l}\text { Purpura and necrotic skin ulcers, } \\
\text { ankle arthr itis and hematuria/ } \\
\text { proteinuria. } \uparrow \text { IgA blood level }\end{array}$ & $\begin{array}{l}\text { Cutaneous leukocytoklastic } \\
\text { vasculitis with IgA deposition }\end{array}$ & Steroids & $\begin{array}{c}\text { Remission of all vasculitis related } \\
\text { symptoms (CR) Moderate renal } \\
\text { insufficiency }\end{array}$ \\
\hline 6 & 46/female & $\begin{array}{c}\text { RPGN and knee/ankle arthritis. } \uparrow \text { IgA } \\
\text { blood level }\end{array}$ & $\begin{array}{l}\text { Endocapillary proliferative GN } \\
\text { with IgA deposition }\end{array}$ & Steroids & $\begin{array}{l}\text { Remission of all vasculitis related } \\
\text { symptoms (CR) } \\
\text { Moderate renal insufficiency }\end{array}$ \\
\hline 7 & 19/female & RPGN and purpura & $\begin{array}{l}\text { Endocapillary proliferative } G N \\
\quad \text { with IgA deposition }\end{array}$ & $\begin{array}{l}\text { Steroids, MTX, } \\
\quad \text { Renal TX }\end{array}$ & $\begin{array}{l}\text { Remission of all vasculitis related } \\
\text { symptoms after renal TX for ESRD }\end{array}$ \\
\hline 8 & 30/male & $\begin{array}{c}\text { Purpura, hematuria/proteinuria, } \\
\text { abdominal pain, knee/ankle arthritis }\end{array}$ & $\begin{array}{l}\text { GN with minimal mesangial } \\
\text { proliferation and IgA deposition }\end{array}$ & Steroids, AZA & $\begin{array}{l}\text { Residual hematuria and } \\
\text { articular pain (PR) }\end{array}$ \\
\hline 9 & 21/female & $\begin{array}{c}\text { Purpura, abdominal pain and melena, } \\
\text { hematuria/proteinuria }\end{array}$ & $\begin{array}{l}\text { GN with minimal mesangial } \\
\text { proliferation and IgA deposition }\end{array}$ & Steroids, AZA & $\begin{array}{l}\text { Remission of all vasculitis related } \\
\text { symptoms }(C R)\end{array}$ \\
\hline 10 & 44/female & $\begin{array}{c}\text { Purpura, polyarthritis, hematuria/ } \\
\text { proteinuria }\end{array}$ & $\begin{array}{l}\text { Endocapillary proliferative GN } \\
\quad \text { with IgA deposition }\end{array}$ & $\begin{array}{l}\text { Steroids, } \\
\text { AZA, CYC. }\end{array}$ & $\begin{array}{l}\text { Remission of all vasculitis related } \\
\text { symptoms }(C R)\end{array}$ \\
\hline 11 & $65 /$ male & Purpura, hematuria & $\begin{array}{l}\text { Endocapillary proliferative GN } \\
\text { with IgA deposition }\end{array}$ & Steroids & Residual hematúria and purpura (PR) \\
\hline
\end{tabular}

Abbreviations: ANA: anti-nuclear antibody; GN: glomerulonephritis; AZA: azathioprine; MTX: methotrexate; PR: partial remission; RPGN: rapid progressive glomerulonephritis; CYC: cyclophosphamide; CR: complete remission; IgA: immunoglobuline A; Tx: transplant; ESRD: end stage renal disease.

as steroid-sparing agents or as additional therapy in patients with progressive systemic vasculitis. Despite the presence of a more severe syndrome in our patients, the final outcome did not differ significantly from the children. It is possible that the good outcome achieved in our adult patients may be somewhat due to a more aggressive therapeutic approach but the design of the present study does not allow some conclusion about the therapeutic approach to HSP. Prospective controlled trials are still indispensable.

In summary, we conclude that HSP seems to represent a distinct clinical syndrome in adults with more severe

\section{REFERÊNCIAS}

1. Ballinger S: Henoch-Schönlein Purpura. Curr Opin Rheumatol 15: 591-4, 2003.

2. Nielsen HE: Epidemiology of Schönlein-Henoch purpura. Acta Paediatr Scand 77: 125-31, 1988. systemic vasculitis and a higher frequency of renal involvement. In an appropriate clinical setting, high $\mathrm{IgA}$ blood levels may suggest the diagnosis that can be confirmed by histological evidence of vasculitis and/or GN with IgA immune deposits. In our series, the final outcome of HSP was as good as reported in children, maybe due to a more aggressive therapeutic approach including steroids and immunosuppressive agents.

Apoio: Produtos Roche Químicos e Farmacêuticos S.A.
3. Blanco R, Martinez-Taboada VM, Rodriguez-Valverde V, GarciaFuentes M, Gonzalez-Gay M: Henoch-Schönlein purpura in adulthood and childhood: two different expressions of the same syndrome. Arthritis Rheum 40: 859-64, 1997.

4. Coppo R, Mazzucco G, Cagnoli L, Lupo A, Schena FP: Longterm prognosis of Henoch-Schönlein nephritis in adults 
and children. Italian Group of Renal Immunopathology Collaborative Study on Henoch-Schönlein purpura. Nephrol Dial Transplant 12: 2277-83, 1997.

5. Garcia-Porrua C, Calvino MC, Llorca J, et al: Henoch-Schönlein purpura in children and adults: clinical differences in a defined population. Semin Arthritis Rheum 32: 149-56, 2002.

6. Pillebout E, Thervet E, Hill G, et al: Henoch-Schönlein Purpura in adults: outcome and prognostic factors. J Am Soc Nephrol 13: 1271-8, 2002.

7. Counahan R, Winterborn MH, White RHR, et al: Prognosis of Henoch-Schönlein nephritis in children. Br Med J 2: 11-4, 1977.

8. Yoshikawa N, White RHR, Cameron AH: Prognostic significance of the glomerular changes in Henoch-Schonlein nephritis. Clin
Nephrol 5: 223-9, 1981.

9. Casanueva B, Rodriguez-Valverde V, Merino J, Arias M, GarciaFuentes M: Increased IgA-producing cells in the blood of patients with active Henoch-Schönlein purpura. Arthritis Rheum 26: 85460,1983

10. Casanueva B, Rodriguez-Valverde V, Luceno A: Circulating IgA producing cells in the differential diagnosis of Henoch-Schönlein Purpura. J Rheumatol 15: 1229-33, 1988.

11. Jennette JC, Falk RJ, Andrassy K, et al: Nomenclature of systemic vasculitides. Proposal of an international consensus conference. Arthritis Rheum 37: 187-92, 1994.

12. Gonzalez-Gay MA, Garcia-Porrua C, Pujol RM: Clinical approach to cutaneous vasculitis. Curr Opin Rheumatol 17: 56-61, 2005. 